\title{
Jason Danely (2014). Aging and Loss: Mourning and Maturity in Contemporary Japan. New Brunswick, NJ: Rutgers University Press, 246 pp. ISBN 9780813565163 (paperback)
}

\author{
REVIEWED by ELS-MARIE ANBÄCKEN*
}

I have read a lot of literature on Japanese society and aging since the early 1990s. A recurring theme is the issue of care and filial duty in a changing society: Who cares, who should care, and where? Danely has composed a unique tapestry which tells the (hi)story of aging, care and intergenerational relations by using aesthetics and spirituality as tools for analysis. In doing so, new aspects of the experience of aging as experiences of loss are dealt with, in the intersections of aging studies, religion and, perhaps, gerontological social work. The ethnography unfolds, starting out from the choice of site and informants to careful interpretations of conversations and participant observations. The in-depth stories and analyses of this interweave with theoretical reflections resulted in a rich "story," which is both an academic study and a piece of fine art.

Throughout the ethnography, Danely uses the cultural reference of Ubasuteyama, the mountain where old grannies were taken by their eldest son to die. Danely draws on this tale in a deeply creative way across time to show that it continues to influence the ways old age care is dispensed till this day. Even though eldercare is available, the view of filial duty as an ideal for care appears to linger on, but interwoven with individual

*Els-Marie Anbäcken, School of Health Care and Social Welfare, Mälardalen University, Eskilstuna, Sweden 
International Journal of Ageing and Later Life

considerations and rooted in feelings of unfulfilled expectations. This theme is interesting to revisit, 15 years after the introduction of the Japanese care insurance to support the independence of elders and their families.

The book is divided into four parts that elucidate the core theme, interpreting the aging experiences of Loss, Mourning, Abandonment and Care, and finally Hope.

The Introduction underlines the importance of seeing population aging as a transformative power in society, as cultural meanings and social institutions change. While I see this throughout the book, I sometimes wished to see more transparency in how the interpretations are constructed, especially on spiritual matters such as the role of cemeteries and family altars. Nevertheless, ethnographies may uncover aspects which are hidden in the taken-for-granted contexts of one's own. In this case, ancestor worship can be linked to different levels, such as population aging, changing family structures, and social policy. The depth of meaning in the rituals surrounding death and the care of the ancestors, as well as the worries that the next generation will not continue this care (in the physical sense but also ancestral "aftercare"), is clear from Danley's informants. I was struck by the similarity we found in a recent study (Anbäcken et al. 2015).

In the first part, Loss, Danely brilliantly interweaves loss, abandonment and aesthetics, and with pregnant words paints a picture of "The Weight of Loss: Experiencing Aging and Grief." The reader feels this weight. I am reminded of Moustakas' Loneliness (1961) on the inevitable existential loneliness of human existence. Both beauty and sadness of loss are linked to narratives. Memorialization is described as both "revealing the structure of loss and its creativity" (p. 26) and also adding to ikigai, a sense of purpose of life. Core concepts developed throughout the book are introduced in Part 1, such as "transience" (p. 21) and "empty space $(m a)^{\prime \prime}$ (p. 23). I find the section "Mourning and Materialization: Debt, Change and Return" (p. 28) especially worth commenting on, since these three words capture the core theme of life and relationships in Japan: keeping the balance of giving and receiving throughout life, in work-, community- and family relations.

In Part 2, Mourning, Danely uses his analysis of the movie Ubasuteyama. Granny Orin demands to be left on the mountain to die, so that by yielding 
Aging and Loss. Book review

to the younger generation, the intergenerational balance and cycle of life could go on. The mountain appears to be a place of redemption and reunion with the spirits of the ancestors. The metaphor continues as "landscapes - inner and outer," which interestingly enough are "psychological and political, natural and built" (p. 69). Danely manages to draw on the image of Kyoto landscapes, with its mountains, rivers, shrines and cemeteries. I was especially moved by a woman's description of the grave as a place to go when "you don't need anything more" (p. 74). Danely draws on the contrast of light and dark of mourning and also on the memorialization through grave artifacts and the family altar, with photos of the deceased.

In Part 3, Abandonment and Care, the Ubasuteyama storyline continues, now in reference to the manga "Abandon the Old in Tokyo." Danely shows that the myth of abandonment was alive well into the 1970s and beyond. He states that there is "a context of uncertainty about the family-provisioned care, social welfare, and care institutions" (p. 142). Danely also adds something original, by transforming the traditional image of filial duty into another level, where dependency and care are made invisible in the "fog" of successful aging. Danley also problematizes dying alone, kodokushi, which often is seen in Japan as a sign of failure - a shameful death for elders, in contrast to the "good death" in the presence of family. This discourse opens up for end-of-life-choices which are very ambiguous in Japan where lifeextending technologies are widely used at hospitals. Even here, Danely finds the link to the Ubasuteyama myth, describing this situation as "another path up" the mountain and saying that "hopes must be revised or lost" (p. 158).

Thus, we come to the fourth and final part, Hope, where Danely labels the Japanese-style welfare as "an ideology of care as abandonment" and says that this paradox is an impossible equation. By not taking care of the older generation at home until the end, professional care becomes psychologically equal to abandonment. Danely includes the political space in his line of thought, although his argument is weakened by the omission of an analysis of harsh economic conditions and the structure of gainful employment and gender (cf. Anbäcken \& Sand 2014). That said, he is far from falling into the trap of unquestioned sociocultural analysis and brings fresh insights through his aesthetics of care, where loss is the focal point. 
International Journal of Ageing and Later Life

Ancestors are a major theme in Danely's ethnography, especially in the way he follows one of his informants, who has struggled throughout the book sorting material things as a kind of life review. The narrative concludes with the story of a dagger which belonged to an ancestor and the ceremony to sanctify it in the temple to be on good terms with the ancestor. Again, as a piece of ethnography, it was deeply interesting and it makes this informant's story end in hope. Yet, as a reflection of Japanese aging and loss, it is perhaps somewhat peripheral. To me, the story of the lengthy farewell through meticulous sorting was even more informative for an analysis of bereavement.

The way Danely paints his ethnographical portrait is excellent, with many depths and details that could be discussed further. However, the fact that the ethnography takes place in Kyoto, "the crib of cultural Japan," calls for additional reflection. Kyoto is an area rooted in thick cultural and religious traditions. With a long personal history in Japan and research on aging and care there, I found myself sometimes questioning whether the leitmotif of relations to ancestors colored the analysis too much. For example, aging communities in large housing complexes in suburban areas, or differences between rural and urban areas, may have provided other perspectives of aging and loss than household altars and graveyards. In light of the changing society of Japan, this would have had added value.

This book has kept me company a couple of months. Its beautiful language requires thoughtful reading to digest the soulful words that continuously flow as a Japanese mountain river. Upon reaching the end of the book, two words from the subtitle echo: "mourning and maturity." I warmly recommend readers of aging and later life to enjoy this aesthetic voyage, which offers new perspectives not only regarding the case of Japan but also of any aging society.

\section{References}

Anbäcken, E., Fujii, M. \& Minemoto, K. (2015). Expressions of identity and self in daily life at a group home for older persons with dementia in Japan. Care Management Journals 16(2): 64-78.

Anbäcken, E.-M. \& Sand, A.-B. (2014). Japan and Sweden with different types of welfare regimes but a similar elderly care development? 
Aging and Loss. Book review

Family care from a gender perspective. In I. Konomi (ed.), “ケア゙学働の社会化に関する国際比較研究 - ジエシダ - 公平な福祉国家の実現に向けで” [An International Comparative Study of the Socialization of Care Work Realizing a Gender Equal Welfare State] (pp. 117-155). Research report 23520791. Nishinomiya: Kwansei Gakuin University.

Moustakas, C. E. (1961). Loneliness. New York: Prentice Hall. 